\title{
Comparison analysis of financial performance telecommunication service which has and has not applied PSAK 73
}

\author{
Deta Merilyn Elintra Kloko ${ }^{1^{*}}$, Bunga Indah Bayunitri ${ }^{2}$ \\ Faculty of Accounting and Business, Widyatama University, Bandung, Indonesia ${ }^{1,2}$ \\ deta.merilyn@widyatama.ac.id ${ }^{I^{*}}$, bunga.indah@widyatama.ac.id $^{2}$
}

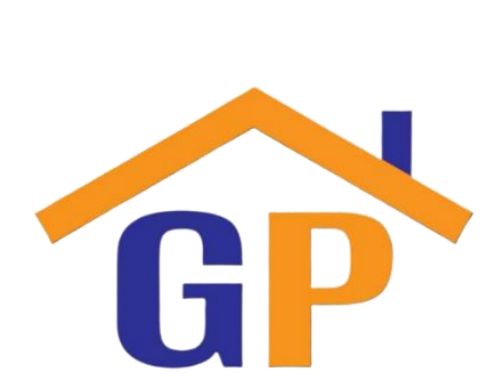

Article History

Received on 21 July 2020

$1^{\text {st }}$ Revision on 12 August 2020

$2^{\text {nd }}$ Revision on 19 August 2020

Accepted on 19 August 2020

\begin{abstract}
Purpose: This research aimed to find out a comparative analysis of the financial performance of companies that has and has not applied the PSAK 73 or IFRS 16 of Lease.
\end{abstract}

Research Methodology: The research used was quantitative descriptive method. The Financial performance analysis performed used a liability, solvency, activity, and profitability ratio.

Results: From the research, it is known that by applying the PSAK 73 on lease in companies has an impact on the financial performance especially on the liability ratio and profitability ratio.

Limitations: The narrowing of the study scope was only to industrial telecommunications due to the inability to collect all data from each type of business. In addition, the application of PSAK 73 in Indonesia was unforced to be implemented in companies in 2019 but in 2020. However, this regulation was possible to apply earlier in 2019 in only corporations meeting requirements. This was aimed at limiting the generalization of study.

Contribution: The result of this study is expected to be useful with regard to the application of PSAK 73 or IFRS 16 of Lease on financial performance in companies.

Keywords: PSAK 73, IFRS 16, Lease, Financial performance How to cite: Kloko, D. M. E., \& Bayunitri, B. I. (2020). Comparison analysis of financial performance telecommunication service which has and has not applied PSAK 73. International Journal of Financial, Accounting, and Management, 2(2), 145-157

\section{Introduction}

Globalization has caused the nature of business throughout the world, including in Indonesia, to reach the international world. Based on data from the Central Statistics Agency on the results of business registration / economic census companies in 2016 showed the number of companies in Indonesia was there were 26.7 million companies. There was an increase compared to the results of the 2006 economic census of 22.7 million companies. There are 3.98 million new companies within ten years in Indonesia (Statistics Indonesia, 2017).

The growth of the company certainly creates intense competition between companies and requires each company to be able to compete with other companies. One of the factors that can influence the company's ability to compete in the competition is the ability of managers to make decisions. The manager's decision must be supported by reliable information so that the decision taken is right for the company's success. In addition to managers, information on a company is also needed by individuals or groups that can influence and / or be influenced by the activities, products or services, and performance of an organization (AA1000 SES, 2015). This then leads to the need for standards or general rules that apply globally so that the information presented has the same understanding for all users. 
According to Harrison et al. (2013) the existence of required accounting standards is needed. Without accounting standards, users of financial statements must learn the basic accounting of each company, then make financial reporting with other companies. The Indonesian Accounting Association (IAI) as an organization involved in making accounting standards since 1994 has implemented a harmonization and adaptation program international accounting standards by issuing International Financial Reporting Standards (IFRS) to PSAK. This program combines with the leaders of countries which are members of the G20, namely creating a set of quality accounting standards that are internationally accepted (Bapepam-LK, 2010).

According to IAI (2012), the IFRS convergence program is expected to improve the quality of information generated by financial statements prepared using internationally accepted financial accounting standards. The impact of the IFRS convergence program is that Financial Accounting Standards is now based on principles, uses fair value, requires professional judgement and more disclosures. In addition to the need for generally accepted accounting standards, companies need to implement strategies to improve business. The one way that companies can do to expand business in the form of financing is by using rent. With the lease, the company does not need to buy fixed assets at a high price. In Indonesia, companies are increasingly busy using leases in their company activities, cite from Jatmiko, (2020), this is evidenced by data from the Financial Services Authority (OJK) which reported that the total assets of companies purchased in Indonesia during 2019 reached Rp518.14 trillion. Visible growth of 2.6 percent from the same period in the previous year. The increasing use of leases requires an approved examination, measurement, presentation, and disclosure of the lease so that information on the financial statements can be accounted for.

In the Exposure Draft (DE) of PSAK 73 concerning leases (2017) explained, the accounting standards on leases have been regulated by IAI in PSAK 30 which was later changed by IAI by adopting IFRS, where PSAK on leases experiences all phases of the rules before January 1, 2012, then January 1, 2012 - December 31, 2019 was changed to PSAK based on principles, and finally on September 18, 2017 due to the ratification of the PSAK 73 Exposure Draft (DE) regarding leases that adopted IFRS 16 Leases effective as of January 1, 2020 by the Financial Accounting Standards Board of the Accounting Association Indonesia (DSAK IAI). PSAK 73 establishes the principles of recognition, measurement, presentation and disclosure of leases by introducing a single accounting model specifically for lessees. Tenants are required to recognize right-of-use assets and lease. liabilities. There are 2 optional exceptions to the recognition of leases for assets and liabilities, namely: (i) short-term leases and (ii) leases that have financial assets its value (underlying assets) is low-value.

In the Exposure Draft (2017) of PSAK 73 for leases, PSAK 73 concerning leases containing IFRS 16 Leases will be effective as of January 1, 2020 in Indonesia, with the option of applying early is permitted for entities that have also applied PSAK 72 (IFRS 15) regarding Revenue from Contracts with Customers. Members of the National Management Board Indonesian Accounting Association (DPNIAI), Rosita Uli Sinaga explained companies that have had to implement IFRS 15 (PSAK 72) and 9 (PSAK 71) in Indonesia are those that have reporting obligations IFRS (Asikin, 2020). Cited from IndoTelko.com (2020), the company that has implemented the early adoption of PSAK 73 of Lease or IFRS 16 of Lease in Indonesia is PT Telekomunikasi Indonesia Tbk (Telkom) which is a company listed on two stock exchanges (two listings) namely the Indonesia Stock Exchange and the New York Stock Exchange (NYSE). As an issuer listed in NYSE, Telkom has the obligation to send IFRS-based financial reports which is also bound by United States Securities and Exchange Commission regulations that have implemented IFRS 15 and 9 since January 1, 2018 and IFRS 16 on January 1, 2019. Furthermore, cited from IndoTelko.com (2020), PT Telekomunikasi Indonesia Tbk (Telkom) became the owner of the largest market capitalization for telecommunications companies listed on the Indonesia Stock Exchange (BEI) throughout 2019, amounting to Rp393.28 trillion. As of December 30, 2019, TLKM's share value reached Rp3,970 per share. (Table 1)

Table 1.1 List of 10 Issuers with the Largest Market Cap on the Indonesia Stock Exchange December 30,2019 


\begin{tabular}{|c|c|c|c|c|c|}
\hline No & $\begin{array}{l}\text { Stock } \\
\text { Code }\end{array}$ & $\begin{array}{c}\text { Company } \\
\text { Names }\end{array}$ & $\begin{array}{l}\text { Stock } \\
\text { Price }\end{array}$ & Listed Shares & $\begin{array}{c}\text { Market Cap } \\
\text { (Billion Rp) }\end{array}$ \\
\hline 1 & BBCA & $\begin{array}{l}\text { Bank Central } \\
\text { Asia Tbk. }\end{array}$ & 33.425 & 24.408 .459 .900 & 815,85 \\
\hline 2 & BBRI & $\begin{array}{l}\text { Bank Rakyat } \\
\text { Indonesia } \\
\text { (Persero) Tbk. }\end{array}$ & 4.400 & 122.112 .351 .900 & 537,29 \\
\hline 3 & TLKM & $\begin{array}{l}\text { Telekomunikasi } \\
\text { Indonesia } \\
\text { (Persero) Tbk. }\end{array}$ & 3.970 & 99.062 .216 .600 & 393,28 \\
\hline 4 & BMRI & $\begin{array}{l}\text { Bank Mandiri } \\
\text { (Persero) Tbk. }\end{array}$ & 7.675 & 46.199.999.998 & 354,58 \\
\hline 5 & UNVR & $\begin{array}{l}\text { Unilever } \\
\text { Indonesia Tbk. }\end{array}$ & 42.000 & 7.630 .000 .000 & 320,46 \\
\hline
\end{tabular}

Source: Bursa Efek Indonesia (2020), processed by the Authors (2020)

Cited from Indotelko.com (2020) Telkom's financial director, Harry M. Zen revealed that PT Telekomunikasi Indonesia Tbk can successfully maintain excellent financial performance and services in a competitive situation that is in addition to focusing on service quality, Telkom also applies rational pricing, maintains profitability, focus on growth in performance, and effective cost management, so that it is able to continue to generate profits and distribute dividends to its shareholders. This is in line with the government program that requires all publicly-listed companies to apply good corporate governance in accordance with international practices as stipulated in the regulation of financial services authority number 21 / POJK.04 / 2015 regarding the application of open corporate governance.

Good corporate governance or called GCG based on SOE Ministerial Regulation Number Per-01 / MMBU / 2011 on August 1, 2011 concerning the application of GCG practices in State-Owned Enterprises that has the principles of transparency, independence, accountability, responsibility, and obligation. PT Telekomunikasi Indonesia Tbk (Telkom) as a state-owned company has implemented GCG in the preparation of its financial statements. As a company listed on two stock exchanges (two listings) namely the Indonesia Stock Exchange and the New York Stock Exchange, Telkom is bound by the Financial Services Authority regulations and the United States Securities and Exchange Commission.

Nur Sigit Warsidin, director of Financial Evaluation of OJK Service Sector Companies (Lingga, 2019), explained that issuers listed in the Indonesia Stock Exchange are still neglecteful in applying the rules of Financial Accounting Standard 73. Although the financial standard instruments must be applied as of January 1, 2020, Nur explained that the OJK as a financial services regulator will impose sanctions on companies that ignore the latest PSAK system. This is in accordance with the Financial Services Authority Regulation Number 29 / POJK.04 / 2016 concerning the Annual Report of Issuers or Public Companies. In article 6 it is explained that the issuer's Annual Report must be prepared in accordance with the provisions regarding the form and content of the Annual Report, the provisions of which are stipulated in the Financial Services Authority Circular, that is, each annual financial report must be prepared in accordance with Indonesian Financial Accounting Standards and audited by an Accountant. This is also in line with the Regulation of the Minister of Trade of the Indonesian Republic Number 25 of 2020 about Company's Annual Financial Report. In Chapter V article 14, it is explained that every company that does not submit Company's Annual Financial Report as intended will be subjected to administrative sanctions, in the form of written warnings, revocation of business licenses and / or operational licenses, and recommendations for revocation of business licenses and / or operational licenses to companies in accordance with statutory provisions.

In previous studies, no one has discussed the comparison between companies that have and have not implemented PSAK 73, therefore, based on the description above, the the Authors would like to see the 
comparison of financial report performance in the telecommunications services industry in Indonesia that has and has not applied the PSAK 73 on Leases.

\section{Literature review}

Indonesia held a conference to IFRS, where the guidelines regarding the previous lease, namely IAS 17 on January 13, 2016 were replaced by IFRS 16 Lease by IASB which was effective from January 1, 2020. Consequently, the main contents of PSAK 30 regarding leases are no longer in accordance with IFRS 16 Leases. Therefore, PSAK 30 has been changed to PSAK 73 on leases which was effective on January 1, 2020 in Indonesia (IAI, 2017). PSAK 73 or IFRS 16 concerning leases regulates the recognition, measurement, presentation and disclosure of leases especially for tenants by only allowing classifying leases as finance leases but for lessees there is no change in the rules. A lease is classified as a finance lease if it transfers substantially all the risks and rewards incidental to ownership of the underlying asset, whereas a lease is classified as an operating lease if the lease does not transfer substantially all the risks and rewards incidental to ownership of the underlying asset. Under PSAK 73, lessees are required to recognize right of use assets and lease liabilities (Indonesian Institute of Accountants, 2012).

The impact of the application of IFRS 16 on rents has been conducted by Imhoff, Lipe and Wright (1991), who examined the impact of constructive operational rent on accounting ratios, developed a uniform set of procedures for estimating the impact of balance sheets that capitalize on lease operations. This process involves using the operating lease disclosures to estimate the amount of debt and assets that would have been reported on the balance sheet if the operating lease had been treated as lease capital from the outset. Tai (2013) examined the impact of rental capitalization on the two food industries in Hong Kong. The results show that both the return on assets and debt-to-equity ratios of the two companies, assuming different discount rates, experience serious decline when operating leases are capitalized. Ozturk and Sercemeli (2016) investigated the impact of the application of IFRS 16 on financial position statement and financial ratios on Turkish airlines. The results show that the valuation of an operating lease on the balance sheet leads to a significant increase in assets and liabilities; therefore there will be a significant increase in the liability / asset ratio and a significant decrease in the return on assets. Diaz \& Ramirez (2018) did a research on the impact of IFRS 16 implementation on financial ratios in European companies. In line with previous research there is an important systematic impact on main balance sheet financial ratios (particularly leverage ratios), to a degree that depends on the intensity of the operating leases of the sector in which the entity operates. Their impact estimates are generally higher than those obtained in previous studies. But based on their researches, they did not find consistent results regarding the effect of the profitability ratio. Safitri, Lestari \& Nurhayati (2019) did a research on the impact of PSAK 73 on financial performance in the manufacturing, mining and service industries. This study uses the constructive capitalization model of rent developed by Imhoff, Lipe and Wright (1991). The results showed that the largest impact of rental capitalization occurred in the service industry, followed by the mining and manufacturing industries with an average increase in Debt to Asset (DAR), Debt to Equity (DER) and a decrease in Return on Assets (ROA) and Return on Equity (ROE). Laksana \& Sudrajat (2019) examined the analysis of Airline Company Financial Report Projection During Transition of PSAK 30 to PSAK 73. The results of this study indicate that the application of PSAK 30 to PSAK 73 has an effect on the entity's income statement. The entity's expenses increase because of additional interest and depreciation expense. Assets also increase. On the other hand the asset management ratio and profitability ratio decrease. Tirani \& Baridwan (2018) examined the analysis of the Impact of the Implementation of PSAK 73 on the Report on Financial Position and Financial Ratios of PT Garuda Indonesia (Persero) Tbk. To analyze the impact of the implementation of PSAK 73 with various transition options, the researcher used the constructive capitalization model of Imhoff, Lipe \& Wright (1991) and Ozturk \& Sercemeli (2016). The results show that if the cumulative retrospective method is applied by PT Garuda Indonesia (Persero) Tbk, the asset balance will increase, while the equity balance will decrease. However, if the asset rights are recorded equal to the amount of the lease liabilities at the beginning of application, the balance of the asset will increase, but does not affect the equity balance in the financial statements. In addition, the implementation of both options result in an increase in the liability. Sari, Altintas \& Tas (2016) examined the effect of the IFRS 16: constructive capitalization of operating leases in the Turkish retailing sector. This study uses 
a constructive capitalization method for these companies. The results show that the new standard have a statistically significant effect on several of the financial ratios tested (debt / assets, debt / equity, return on assets (ROA) and return on equity (ROE)).

From previous research, it is known that the existence of IFRS 16 or PSAK 73 companies need to change the bookkeeping method of operating leases to financial leases, except for lease transactions that meet two conditions, namely short term and low value. Previous research used lease capitalization to determine the impact of IFRS 16 or PSAK 73 implementation on the company's financial performance. In addition, from several previous studies, it is known that the biggest impact of capitalization occurs in the service industry, then the mining industry and manufacturing of Financial Performance. The results of previous studies also explained that the implementation of IFRS 16 / PSAK 73 in companies had an effect on financial ratio standards. The results of Tai (2013), Safitri, Lestari, \& Nurhayati (2019), and Laksana and Sudrajat (2019) research ROA and ROE when implementing PSAK 73 / IFRS 16 decreased, while according to Ulayya, ROA and ROE had increased. This becomes interesting to research. Thus, from previous research, no one discussed the comparison of financial performance between companies that have and have not implemented IFRS 16 or PSAK 73 in the same type of industry. Therefore, the the Authors would like to see the comparison of financial report performance in the telecommunications services industry in Indonesia that has and has not applied the PSAK 73 Lease.

\section{Research methodology}

The sample selection was applied using nonprobability sampling and purposive sampling technique. The criteria for determining the sample are telecommunications service sector companies listed on the Indonesia Stock Exchange in 2019, telecommunications service companies that published their financial reports that have been audited on the Indonesia Stock Exchange, telecommunications service sector companies that have lease transactions in 2019 and have not applied the PSAK 73 for rent in their financial statement. The data for this research were collected through literature study and documentation study. In this study, the data were analyzed by calculating the financial ratios of each company sample from their financial statement in 2019 and analyzing the ratios. Ratio measurements used include: Profitability Ratios, Leverage Ratios, Activity Ratios, and Liquidity Ratios. Sugiyono (2017) explores quantitative research interpreted as a method" positive because it is based on positivism, which is used for consideration of samples or samples, collecting data using research instruments, quantitative / statistical data analysis.

Descriptive statistics according to Silalahi (2015: 530) for distribution variables and relationship variables. Descriptive statistics are statistics that give an overview or describe data that are seen from the average (average), median, minimum, maximum, standard deviation, slope of the distribution (slant distribution) and kurtosis (Ghozali Imam, dan R, Dwi, 2017).

In this study, the author will describe the impact of the adoption of PSAK 73 on rent on financial performance by calculating each financial statement ratio of each study sample. After that the the Authors compares the financial ratios between the sample companies that has and has not applied PSAK 73 on rent. By comparing the ratio of companies that have and have not applied PSAK 73 it can be seen the impact of the application of PSAK 73 on telecommunications service companies.

Data analysis techniques in analyzing data in this study are as follows:

1. Calculate data. Calculate data by calculating the financial ratios of each company sample from the 2019 financial statement data, which is the following formula (Kasmir 2017: 138):

1. Liquidity Ratio

a. Current ratio $=$ Current assets $/$ Current Debt

b. Quick Ratio $=($ Current Assets - Inventory $) /$ Current Debt

c. Cash Ratio $=($ Cash + Cash Equivalents $) /$ Current Debt

2. Solvency Ratio

a. Debt to Asset Ratio (Debt Ratio) $=$ Total debt $/$ Total assets 


\section{Activity Ratio}

b. Debt to Equity Ratio = Total Debt / Equity

a. Receivable Turn Over $=$ Sales $/$ Receivables

b. Working Capital Turn Over Ratio = Net Sales / Working Capital

c. Asset Turnover $($ Total Asset Turn Over $)=$ Sales $/$ Total Assets

4. Profitability Ratio
a. Net Profit Margin = Earning Before Interest and Tax $($ EBIT $) /$ Sales
b. Return to Investment $($ ROI $)=$ Earning After Interest and Tax / Total Assets
c. Return on Equity $(\mathrm{ROE})=$ Earning After Interest and Tax / Equity

2. Analyze data. After obtaining the ratio calculation results for each company, a financial ratio analyst can do as follows:

a. Comparing the financial ratios of each company in 2019 who have and have not applied PSAK 73 for rents to their financial performance.

b. Analyze the financial ratios of each company based on the circumstances of each company.

Data processing in this study was carried out with the following procedure:

1. Researchers collected data on the annual financial statements of telecommunications service companies listed on the Indonesia Stock Exchange in 2019 as a research sample.

2. Researchers collect data related to the variables studied in the study. The data collected by researchers is a measure of corporate financial performance, namely liquidity ratios, solvency ratios, activity ratios, and profitability ratios.

3. Researchers process the data that has been collected using ratio formulas then analyze the results of these calculations.

4. Researchers draw conclusions from the results of calculations performed.

\section{Results and discussions}

The object of research in this study is service sector companies listed on the Indonesia Stock Exchange in 2019 with indicators of financial statement performance assessed through profitability ratios, solvency ratios, liability ratios, and corporate activity ratios. The dependent variable in this study is PSAK 73 on rent while the independent variable in this study is the performance of financial statements which are proxied by profitability ratios, solvency ratios, liability ratios, and company activity ratios.

\section{Financial Statement Performance Analysis}

The following is a statistical analysis of the variables used in the study. Descriptive statistical analysis presents the smallest value, the largest value, the average value, and the standard deviation. In this descriptive analysis it will be seen the performance of the financial statements of each company that has and has not applied PSAK 73 for rent in their financial statements. In PSAK 73 for leases, the lessee is required to recognize the right of use assets and lease liabilities. But there are two optional exclusions in the recognition of leased assets and liabilities, namely for short-term leases (less than 12 months) and rents for which underlying assets are of low value. In addition, the lessee classifies it as an operating lease or a finance lease and records the two types of leases differently. Based on the methods and calculations that have been done by the the Authors, the result is as follows:

Table 4.1 Financial Ratio of Each Company

\begin{tabular}{|l|r|r|r|r|r|}
\hline Explanation & \multicolumn{1}{|l|}{ TLKM } & \multicolumn{1}{l|}{ JSAT } & EXCL & \multicolumn{1}{l|}{ FREN } & \multicolumn{1}{l|}{ ISAT } \\
\hline Liquidity Ratio & 71,48 & 138,02 & 46,37 & 29,00 & 56,24 \\
\hline Current Ratio & 70,48 & 138,02 & 45,88 & 28,01 & 56,10 \\
\hline Quick Ratio & 31,25 & 2,35 & 10,40 & 3,22 & 26,58 \\
\hline Cash Ratio & \multicolumn{7}{|l|l|}{} \\
\hline Solvency Ratio & $47 \%$ & $40 \%$ & $70 \%$ & $54 \%$ & $78 \%$ \\
\hline DAR & $89 \%$ & $66 \%$ & $228 \%$ & $117 \%$ & $358 \%$ \\
\hline DER
\end{tabular}




\begin{tabular}{|c|c|c|c|c|c|}
\hline \multicolumn{6}{|l|}{ Activity Ratio } \\
\hline $\begin{array}{l}\text { Account } \\
\text { turnover }\end{array}$ & 11 & 2 & 30 & 71 & 9 \\
\hline Working capital turnover & 0,91 & 0,04 & 0,16 & 1,32 & 0,13 \\
\hline Assets turnover & 0,61 & 0,69 & 0,40 & 0,25 & 0,42 \\
\hline \multicolumn{6}{|l|}{ Profitability Ratio } \\
\hline ROI & $12 \%$ & $3 \%$ & $1 \%$ & - & $3 \%$ \\
\hline ROE & $24 \%$ & $4 \%$ & $4 \%$ & - & $12 \%$ \\
\hline NPM & $28 \%$ & $3 \%$ & $5 \%$ & - & $6 \%$ \\
\hline
\end{tabular}

Source: Bursa Efek Indonesia (2020), processed by the Authors (2020)

\section{Financial Performance Analysis of PT Telekomunikasi Indonesia Tbk (Telkom)}

Liquidity Ratio: From the calculation that has been done, it is known that the current ratio of PT Telkom in 2019 is $71.48 \%$. A current ratio of $71.48 \%$ means that every Rp1, - current debt is guaranteed to be refunded by assets of Rp.7,7148. This is in accordance with the effect of the adoption of PSAK 73 in companies because every company that applies PSAK 73 will recognize finance leases as a rental obligation during the lease period so that the decrease in the current ratio of the company is reasonable due to an increase in the number of debts on the debt or liability post. The current ratio in 2019 has decreased compared to the previous year (2018) which was 93.5\% (Telkom, 2020). A quick ratio value of less than $100 \%$ indicates that the company's ability is not good, meaning that the current ratio in the company indicates that PT Telkom's ability is not good in fulfilling its current obligations or it can be said that it is not yet in a good position. PT Telkom's quick ratio is $70.48 \%$. The cash ratio is $31.25 \%$, which means that PT Telkom has a smaller amount of cash and cash equivalents compared to the company's current liabilities. this value is considered not good because the cash ratio shows the availability of cash and cash equivalents to pay short-term debt. A company is said to be good if the ratio of cash or cash equivalents to its debt is $1: 1$ which means the company can pay off debts that will soon mature with cash and cash equivalents they have. But even so if cash and cash equivalents are large, they can be considered as unproductive cash and the company is considered unable to properly utilize its cash.

Solvency Ratio: Debt to Asset Ratio (DAR) of PT Telkom is $47 \%$. This means that the total assets funded by debt are $47 \%$ of the assets owned by the company. The higher the DAR value means the higher the debt the company has for the purchase of its assets. DER values below 1 or $100 \%$ indicate that the level of debt at PT Telkom is lower than the assets it has. DER of PT Telekomunikasi Indonesia Tbk in 2019 experienced a slight increase compared to 2018. PT Telkom's 2018 DER is $43.1 \%$ (Telkom, 2020). This is in accordance with the impact of the adoption of PSAK 73 on companies, because every company that applies PSAK 73 will recognize usufructuary assets so that the postal on assets will rise and recognize liabilities on leases so that liabilities to the company will also increase, but every year the usufructuary assets will decrease due to depreciation of usufruct assets and liability items will decrease when the company pays the debt on the lease. PT Telkom's Debt to Equity Ratio (DER) in 2019 is $89 \%$. This means that company funding provided by shareholders is quite high, which means the smaller the company's burden on outsiders. In addition, DER is $89 \%$ or less than $100 \%$, reflecting the company's ability to pay its obligations due to the lower ratio, the higher the company's funding provided by shareholders and the smaller the company's burden on outsiders. This ratio increased compared to the previous year, which was $75.8 \%$ (Telkom, 2020).

Related to the application of PSAK 73 in PT Telkom, PSAK 73 will cause an increase in the liability account due to the recognition of the finance lease debt and if viewed from the annual financial statements of PT Telkom in 2018 when PT Telkom has not applied PSAK 73 for the full lease, there is no additional paid-in capital, it can be assumed that equity rises from profit alone, but the profit has been affected by the depreciation of usufructuary assets and deferred tax burden on rent, this means an increase in DER in accordance with the impact of the application of PSAK 73, namely a decrease in the 
company's ability to guarantee its debt which increased because there is the application of PSAK 73 on rent to own capital.

Activity Ratio: From the calculation that has been done, it is found that PT Telkom's account receivable turnover is 11 times. PT Telkom's working capital turnover in the 2019 financial statements is 0.91 times. In the previous year (2018), PT Telkom's working capital turnover was 0.6 times. This means there is an increase in working capital turnover. This means there is an increase in working capital turnover, should with this increase in working capital PT Telkom is able to generate higher net sales, this is evident revenue in 2019 of 135,567 billion rupiah is greater than in 2018 which amounted to 130,784 billion rupiah (Telkom, 2020). Asset turnover at PT Telkom is 0.61 times. Asset turnover is obtained from measuring sales volume divided by total assets, meaning that asset turnover at PT Telkom is good, because the faster the asset turnover, the more efficient the use of assets at the company, so the greater the revenue generated by PT Telkom by using the assets it has.

When compared with 2018, PT Telkom's asset turnover is 0.63 times or less than 1 time per year, this figure can be said to be as good as the assets turnover in 2019. The existence of the application of PSAK 73 on leases should cause an increase in the asset post on the balance sheet because PSAK 73 on leases requires all leases that do not qualify as operating leases to recognize the usufructuary rights on the financial statements, even though the impact is not too significant but when viewed in PT Telkom's financial statements in 2019 the number of assets is smaller than the total assets in 2018, this might occur because assets are affected by asset depreciation, asset sales in 2019, and asset purchases in 2018 . In addition, sales in 2019 also increased compared to 2019, thus affecting the turnover of assets.

Profitability Ratio: Return On Investment at PT Telkom in 2019 is $12 \%$. The positive value generated illustrates that the investment in PT Telkom provides a good return and indicates the total investment cost can be returned so that profits will be obtained from the remaining investment costs. In addition, ROI of $12 \%$ means that every Rp1, - the total investment invested in the company is able to produce Rp0.12, - the remaining operating results. ROI also reflects Return on Assets to the company. Return on Investment in the company is 13\%. ROA at PT Telkom decreased from 2018 to 2019. This is in accordance with the impact of the adoption of PSAK 73 on leases in the financial statements will affect the asset post because of recognition of right-of-use assets as well as profits will be affected due to interest expense on lease liabilities and depreciation expense of right-of-use asset. Return on Equity at PT Telkom is $24 \%$. In 2018 ROE at PT Telkom was $22 \%$, which means there was an increase in ROE from 2018 to 2019. The adoption of PSAK 73 on rent affects the decrease in equity in the company due to the depreciation of the right to use assets and the deferred tax burden on the lease. But if seen from PT Telkom there is an increase in ROE, this can be affected due to an increase in equity from the sale of fixed assets, the results of the placement of other current financial assets - net, the results of the disposal of the subsidiary, the results of insurance claims, receipt of advances and assets others, and dividends received from associates that are greater than 2018 so that equity in 2019 increases. This is the same as the results of the research by Diaz \& Ramirez (2018) which state that there are no consistent results with regard to the effect of the profitability ratio. Net Profit Margin (NPM) at PT Telkom is $28 \%$. Compared with 2018, PT Telkom's NPM is $28 \%$. This indicates that the company can effectively manage its operating costs.

\section{Financial Performance Analysis of PT Jasnita Telekomindo Tbk}

Liquidity Ratio: The current ratio of PT Jasnita Telekomindo in 2019 is $138.02 \%$, which is a very good number. The quick ratio of PT Jasnita Telekomindo Tbk is $138.02 \%$. The cash ratio is $2.35 \%$. This number is considered poor.

Solvency Ratio: Debt to Asset Ratio (DAR) of PT Jasnita Telekomindo Tbk is $40 \%$. This means that the total assets funded by debt is $40 \%$ of the assets owned by the company. Additionally, the company's ability to pay obligations is excellent. This indicates that the assets owned by PT Jasnita Telekomindo Tbk can cover their obligations. Debt to Equity Ratio (DER) of PT Jasnita Telekomindo Tbk in 2019 is $66 \%$. 
Activity Ratio: The results of PT Jasnita Telekomindo Tbk's account receivable turnover are 2 times. The working capital turnover of PT Jasnita Telekomindo Tbk in the 2019 financial statements was 0.04 times, while the assets turnover is 0.69 times.

Profitability Ratio: Return On Investment at PT Jasnita Telekomindo in 2019 is 3\%. Return On Equity at PT Jasnita Telekomindo Tbk is 4\%. Net Profit Margin (NPM) at PT Jasnita Telekomindo Tbk is 3\%.

\section{Financial Performance Analysis of PT XL Axiata Tbk}

Liquidity Ratio: Based on the calculation aforcited, it is known that the current ratio of PT XL Axiata Tbk in 2019 is $46.37 \%$ or less than $100 \%$. Current ratio of $46.37 \%$ means that every 1 rupiah of debt due is guaranteed by 0.4637 rupiah of fixed assets owned by the company. The quick ratio at XL Axiata Tbk is $45.88 \%$. This means that every 1 rupiah of current debt is guaranteed by liquid assets of 0.4588 rupiah. The cash ratio is $10.40 \%$, which means that PT XL Axiata Tbk has a smaller amount of cash compared to the company's current liabilities.

Solvency Ratio: Debt to Asset Ratio (DAR) of PT XL Axiata Tbk is 70\%. This means that the total assets funded by debt is $70 \%$ of the assets owned by the company. Debt to Equity Ratio (DER) of PT XL Axiata Tbk in 2019 is $228 \%$. The results of this calculation illustrate the state of the company that is unhealthy.

Activity Ratio: PT XL Axiata accounts receivable turnover is 30 times. This means that the company collects accounts receivable relatively fast. PT XL Axiata's working capital turnover in the 2019 financial statements was 0.16 times. The value of 0.16 reflects the working capital turnover at PT XL Axiata is low throughout the year. Asset turnover at PT XL Axiata is 0.4 times, which means assets turnover at PT XL Axiata is unsatisfactory.

Profitability Ratio: Return On Investment at PT XL Axiata Tbk in 2019 is 1\%. The positive value illustrates that investment in PT XL Axiata Tbk provides a good return, and it signifies the total investment cost can be returned so that profits will be obtained from the remaining investment costs. Return On Equity at PT XL Axiata Tbk is 4\%. Net Profit Margin (NPM) at PT XL Axiata Tbk is 5\%. This shows the ability of PT XL Axiata Tbk in processing its company's operations is unsatisfactory.

\section{Financial Performance Analysis of PT Smartfren Telecom Tbk}

Liquidity Ratio: Current ratio of PT Smartfren Telecom Tbk in 2019 is $29 \%$ or less than $100 \%$. The quick ratio of PT Smartfren Telecom Tbk is $28.01 \%$. The cash ratio at PT Smartfren Telecom is $3.22 \%$, which means PT Smartfren Telecom Tbk has a smaller amount of cash compared to the company's current liabilities.

Solvency Ratio: From the calculation that has been done, it is known that the Debt to Asset Ratio (DAR) of PT Smartfren Telecom Tbk is 54\%. PT Smartfren Telecom's 2019 Debt to Equity Ratio (DER) is $117 \%$. The results of this calculation illustrate a fairly healthy state of the company.

Activity Ratio: PT Smartfren accounts receivable turnover is 71 times. This means that the company collects accounts receivable relatively fast. PT Smartfren Telecom's working capital turnover in the 2019 financial statements was -1.32 times. Negative capital is the accumulation of losses experienced by the company, or it identifies that the company has suffered losses for some backward periods. Therefore, the capital turnover does not need to be calculated because the company suffered losses. Asset turnover at PT Smartfren Telecom Tbk is 0.25 times, which means assets turnover at PT Smartfren Telecom is unsatisfactory.

\section{Financial Performance Analysis of PT Indosat Tbk}


Liquidity Ratio: The current ratio of PT Indosat Tbk in 2019 is 56.24\%. The result of quick ratio calculation at PT Indosat Tbk is $56.10 \%$. The cash ratio at PT Indosat Tbk is $26.58 \%$. This means that PT Indosat Tbk has a greater amount of liabilities compared to its cash.

Solvency Ratio: Debt to Asset Ratio (DAR) of PT Indosat Tbk is 78\%, which means the company's ability to pay short-term obligations is quite good. PT Indosat Tbk Debt to Equity Ratio (DER) in 2019 is $358 \%$.

Activity Ratio: The result of PT Indosat Tbk's account receivables turnover is 9 times. This means that the company is quite good in collecting account receivables. PT Indosat Tbk's working capital turnover in the 2019 financial statements was 0.13 times. Asset turnover at PT Indosat Tbk is 0.42 times.

Profitability Ratio: Return On Investment at PT Indosat Tbk in 2019 is 3\%. Return On Equity at PT Indosat is $12 \%$. From this figure, it can be interpreted that for every 1 rupiah of shareholders' equity, the company can process it into 0.12 rupiah of the company's net profit. Net Profit Margin (NPM) at PT Indosat Tbk is 6\%.

Comparative Of Financial Perfomance Telecommunication Service Companies which Has Applying PSAK 73 with Financial Perfomance Telecommunication Service Companies which Has Not Applying PSAK 73 Listed In Indonesia Stock Exchange In 2019

From the results of the analysis of the financial statements of each companies above, it is known that PT Telekomunikasi Indonesia Tbk, as a company that has applied PSAK 73 for rent, has a better financial performance compared to companies that have not applied PSAK 73 for rent. Looking from the liquidity ratio, PT Jasnita Telekomindo Tbk is in the highest liquidity order, or it has the best liquidity ratio with current ratio of $138.02 \%$, quick ratio of $138.02 \%$, and cash ratio of $2.35 \%$. It is followed by PT Telekomunikasi Indonesia Tbk which has current ratio $71.38 \%$, quick ratio $70.48 \%$, and cash ratio $31.25 \%$. Then, it is followed by PT Indosat Tbk which has a current ratio of 56.24, quick ratio of $56.1 \%$, and cash ratio of $26.58 \%$. After which, it is followed by PT XL Axiata Tbk which has a current ratio of $46.37 \%$, a fast ratio of $45.88 \%$, a cash ratio of $10.4 \%$. In the last place is PT Smartfren Telecom Tbk with a current ratio of $29 \%$, a quick ratio of $28.01 \%$, and cash ratio of $3.22 \%$.

Looking from the solvency ratio, the company that has the lowest DAR is PT Jasnita Telekomindo Tbk by $40 \%$. Then it is followed by PT Telekomunikasi Indonesia Tbk by $47 \%$. The third company with the lowest DAR is PT XL Smartfren Telecom Tbk. It is followed by PT XL Axiata with 70\%. The last is PT Indosat Tbk with DAR of 78\%. Whereas DER, if ranked from the lowest, is PT Jasnita Telekomindo Tbk with a DER of $66 \%$, PT Telekomunikasi Indonesia Tbk with $89 \%$, then followed by PT Smartfren Telecom Tbk with $117 \%$, PT XL Axiata Tbk with 228\%, and finally PT Indosat Tbk with DER of $358 \%$.

From account receivable turnover ratio aspect, PT Smartfren Telecom Tbk is the highest with 71 times, followed by PT XL Axiata Tbk with account receivable turnover 30 times, PT Telekomunikasi Indonesia Tbk with account receivable turnover 11 times, PT Indosat Tbk with account receivable turnover 9 times, and in the last place is PT Jasnita Telekomindo Tbk with account receivable turnover of 2 times. For the highest working capital turnover is PT Telekomunikasi Indonesia Tbk 0.9 times, followed by PT XL Axiata Tbk by 0.13 times, PT Indosat Tbk by 1 time, and PT Jasnita Telekomindo Tbk by 0.04 times. For PT Smartfren Telecom Tbk, the working capital turnover is negative. On the other hand, the highest asset turnover is PT Jasnita Telekomindo Tbk 0.69 times, then PT Telekomunikasi Indonesia Tbk 0.61 times, PT Indosat Tbk was 0.42 times, PT XL Axiata Tbk was 0.4 times, and the last is PT Smartfren Telecom Tbk, which is 0.25 times.

From the profitability ratios calculated above, the company with best ROI results is PT Telekomunikasi Indonesia Tbk with 12\%. It is followed by PT Jasnita Telekomindo Tbk and PT Indosat Tbk with same ROI of 3\%, and PT XL Axiata Tbk by 1\%. PT Smartfren experienced a loss so the ROI cannot be calculated. For ROE, the best return on equity is PT Telekomunikasi Indonesia Tbk with a ratio of $24 \%$, PT Indosat Tbk with ROE with 12\%, PT Jasnita Telekomindo Tbk and PT XL Axiata Tbk with the 
same ROE value of 4\%. Meanwhile, if viewed from the NPM, the company with the best NPM is PT Telekomunikasi Indonesia Tbk with 28\% NPM, followed by PT Indosat Tbk with 6\%, PT XL Axiata Tbk with 5\% NPM, and the last is PT Jasnita Telekomindo Tbk with NPM of 3\%.

\section{Conclusion}

In the Exposure Draft (2017) of PSAK 73 for leases, PSAK 73 concerning leases containing IFRS 16 Leases will be effective as of January 1, 2020 in Indonesia, with the option of applying early is permitted for entities that have also applied PSAK 72 (IFRS 15) regarding Revenue from Contracts with Customers. The company that has implemented the early (in 2019) adoption of PSAK 73 of Lease or IFRS 16 of Lease in Indonesia is PT Telekomunikasi Indonesia Tbk (Telkom) which is a company listed on two stock exchanges (two listings) namely the Indonesia Stock Exchange and the New York Stock Exchange (NYSE). The Authors process the data that has been collected from the report data which has been audited namely from The Indonesia Stock Exchange calculates and analyzes using ratio formulas then analyze the results of these calculations. After that the Authors compare the financial ratios between the sample companies that has and has not applied PSAK 73 on rent.

Based on the results of this research, it is known that in 2019, the application of PSAK 73 on rent at PT Telekomunikasi Indonesia Tbk (Telkom) has been done well. This is supported by independent auditors opinion, KAP Purwantono, Sungkoro \& Surja, that said PT Telekomunikasi Indonesia Tbk (Telkom) consolidated financial statements in 2019 were presented fairly in all material respects or Unqualified Opinion (Telkom, 2020). In addition, it is known that PT Telekomunikasi Indonesia Tbk has a good financial statement performance compared to companies that have not applied PSAK 73 on rent. This is evidenced by the liquidity ratio being the second most liquid company, in terms of the solvency ratio of PT Telekomunikasi Indonesia Tbk is second in the company that is able to guarantee its debt with capital and activities, besides that in terms of its activity ratio PT Telekomunikasi Indonesia Tbk is ranked first for Working capital turnover and the second fastest turnover in accounts receivable and assets turnover compared to companies that do not apply PSAK 73 on leases in their financial reporting, besides, in terms of profitability ratios, PT Telkom ranks best in ROI and ROE compared to service companies other telecommunications registered on the stock exchange in 2019. This is the same as the results of the research by Diaz \& Ramirez (2018) which state that there are no consistent results with regard to the effect of the profitability ratio.

\section{Limitation and study forward}

The Authors would like to give a few suggestions that are hoped to be a valuable input for future research. Future researchers can choose service sector companies other than telecommunications, trade or manufacturing sectors. In addition, future researchers can choose variables that are not influenced by financial performance, for example, their impact on company income tax, the company's stock trading activities, their impact on the relevant value of accounting information on a company, or analyze other factors that affect financial performance.

\section{Acknowledgement}

The authors would like to thank Mrs. Bunga Indah Bayunitri, S.E., M.M., Ak., C.A. as the supervisor who has taken her time to provide the Authors with practical direction, guidance, and input. Also, all parties who have given great thoughts and favorable comments in the completion of the research. Thank you for your support and prayers.

\section{References}

AA1000SES. (2015). AA1000SES (2015) Stakeholders. Retrieved April 27, 2020, from www.accountability.org

Asikin, M N. (2020). Dewan Standar Akuntansi Keuangan Siap Berlakukan PSAK Baru Awal 2020.

Retrieved April 27, 2020, from
https://www.jawapos.com/ekonomi/finance/28/03/2019/dewan-standar-akuntansi-keuangansiap-berlakukan-psak-baru-awal-2020/ 
Badan Pengawas Pasar Modal dan Lembaga Keuangan. (2010). Kajian tentang pedoman gcg di negaranegara anggota ACMF. Jakarta.

Badan Pusat Statistik. (2017). Hasil Pendaftaran Usaha/Perusahaan Sensus Ekonomi 2016. Retrieved March 14, 2020, from https://www.bps.go.id/pressrelease/2017/04/27/1404/hasil-pendaftaran-listing--usaha-perusahaan-sensus-ekonomi-2016.html

Badan Pusat Statistik. (2020). Laporan Keuangan dan Tahunan. Retrieved March 17, 2020, from https://www.idx.co.id/perusahaan-tercatat/laporan-keuangan-dan-tahunan/

Bursa Efek Indonesia. (2019). Ringkasan Saham. Retrieved, March 17, 2020, from https://www.idx.co.id/data-pasar/ringkasan-perdagangan/ringkasan-saham/

Ghozali, Imam, \& R, Dwi. (2017). Analisis multivariate dan ekonometrika dengan eviews 10. Badan Penerbit Universitas Diponegoro: Semarang.

Harrison, Jr., Walter, T., Charles, T.. Horngren, C, W. T. \& T, Suwardy. (2013). Financial accounting eighth edition. Singapore : Pearson Education, Inc.

Ikatan Akuntan Indonesia. (2012). Standar akuntansi keuangan. Jakarta: Salemba Empat.

Ikatan Akuntan Indonesia. (2017). Draf eksposur PSAK 73 sewa. Jakarta: Ikatan Akuntan Indonesia.

Imhoff, Lipe \& Wright. (1991). Operating leases: impact of constructive capitalization. Accounting Horizons, 5(1).

Diaaz, M \& Ramirez, Z. (2018). The impact of IFRS 16 on Key Financial Ratios: A New Methodological Approach. Accounting in Europe, vol. 15, no. 1, pp.

Jatmiko, B. (2020). OJK: Total aset perusahaan pembiayaan tumbuh 2,6 persen sepanjang 2019. Retrieved March 14, 2020, from https://money.kompas.com/ read/2020/02/20/124400926/ojk-total-aset-perusahaan-pembiayaan tumbuh -2-6-persen-sepanjang-2019

Kasmir. (2017). Analisis laporan keuangan. Jakarta: PT Rajagrafindo Persada.

Lakasana \& Sudrajat. (2019). analisis proyeksi laporan keuangan perusahaan penerbangan saat transisi PSAK 30 menjadi PSAK 73. Bogor: Institut Bisnis dan Informatika Kesatuan.

Lingga, N. (2019). Emiten belum efektif implementasikan standar akuntansi keuangan. Retrieved May 28, 2020, from https://money.kompas.com/read/2019/05/02/184900526/emiten-belum-efektifimplementasikan-standar-akuntansi-keuangan

IndoTelko.com. (2020). Kisah Telkom terapkan PSAK 71, 72, dan 73. Retrieved, April 27, 2020, from https://www.indotelko.com/read/1557446052/kisah-telkom-73

IndoTelko.com. (2020). Saham Telkom masuk 3 besar "Big Cap" di 2019. Retrieved, March 15, 2020, from https://www.indotelko.com/read/1577932076/saham-telkom-big

IndoTelko.com. (2020). Telkom ungkap rahasia menjaga perkembangan bisnis. Retrieved, March 17, 2020, from https://www.indotelko.com/read/1575279349/telkom-menjaga-bisnis

Ozturk \& Sercemeli. (2016). Impact of new standard "IFRS 16 leases on statement of financial position and key ratios: a case study on an airline company in Turkey. Business and Economics Research Journal, 7(4).

Peraturan Otoritas Jasa Keuangan Nomor 29/POJK.04/2016 tentang laporan tahunan emiten atau perusahaan publik. 29 July 2016. Board of Commissioners of the Financial Services Authority. Jakarta.

Peraturan Menteri Negara Badan Usaha Milik Negara Nomor : PER - 01/MBU/2011 tentang penerapan tata kelola perusahaan yang baik (Good corporate governance). 01 August 2011. Republic of Indonesia State Institution. Jakarta.

Peraturan Otoritas Jasa Keuangan Nomor 21/pojk.04/ 2015 tentang penerapan pedoman tata kelola perusahaan terbuka. 30 November 2015 Board of Commissioners of the Financial Services Authority. Jakarta.

Regulation of the Minister of Trade of the Indonesian Republic Number 25 of 2020, Company's Annual Financial Report. 16 March 2020. Republic of Indonesia State Institution. Jakarta.

Safitri, Lestari \& Nurhayati. (2019). Analisis dampak penerapan PSAK 73 atas sewa terhadap kinerja keuangan pada industri manufaktur, pertambangan, dan jasa yang terdaftar di Bursa Efek Indonesia Tahun 2018. Bandung: Politeknik Negeri Bandung. 
Sari, E., Altintas, T., and Tas, N. (2016). The effect of The IFRS 16: Constructive capitalization of operating leases in the Turkish retailing sector. Press Academia.

Silalahi, U. (2015). Metode penelitian sosial kunatitatif. Bandung: PT Refika Aditama.

Sugiyono. (2017). Metode penelitian kuantitatif, kuantitatif, dan R\&D. Bandung: CV Alfabeta.

Tai. (2013). Constructive capitalization of operating leases in the Hongkong fast-food industry. International Journal of Accounting and Financial Reporting ISSN 2162-3082 2013, 3(1).

Telekomunikasi Indonesia. (2020). Laporan keuangan. Retrieved June 30, 2020, from https://www.telkom.co.id/sites/about-telkom/id_ID/page/ir-laporan-keuangan

Tirani, U., \& Baridwan., Z. (2018). Analisis dampak implementasi PSAK 73 terhadap laporan posisi keuangan rasio keuangan PT Garuda Indonesia (Persero) Tbk. Yogyakarta: Universitas Gajah Mada. 